\title{
Socialization of Efforts to Increase Environmental Awareness in Pangambatan Village as A Tourist Attraction in Karo Regency
}

\author{
Flansius Tampubolon ${ }^{1 *}$, Jekmen Sinulingga ${ }^{1}$ \\ ${ }^{1}$ Fakultas Ilmu Budaya, Universitas Sumatera Utara, Medan, Indonesia \\ *Email: jekmen@usu.ac.id
}

\begin{abstract}
This service aims to provide environmental care socialization in Pangambat village. As a tourist village, Pangambaten village has problems in dealing with environmental challenges related to environmental cleanliness, so there is a need to educate and inform the community about environmental problems. One of the commitments of the international community and government in protecting the earth from pollution and damage is through the implementation of Environmental Education, which is the key to preparing people with knowledge, expertise, values and a caring attitude so that they can actively participate in solving environmental problems. The counseling on environmental care in this service program is intended as an initial step in building a character that cares about the environment in the community. This service was carried out in Pangambaten, Tanah Karo Regency, North Sumatra Province. This service is carried out in two methods, namely the interactive presentation method. This service activity is carried out in the following stages: 1) Equalization of Community Group Perceptions, 2) Group coaching, 3) Counseling on understanding about fostering environmental concern for environmental cleanliness by reviving the tradition of mutual cooperation.
\end{abstract}

Keyword: Pangambat Village, Local Wisdom, Environmental Service.

\begin{abstract}
Abstrak
Pengabdian ini bertujuan untuk memberikan sosisalisasi peduli lingkungan di desa pangambatan. Sebagai desa wisata, desa Pangambaten mempunyai masalah dalam menghadapi tantangan lingkungan terkait dengan kebersihan lingkungan, sehingga muncul kebutuhan untuk mendidik dan memberi informasi kepada masyarakat mengenai permasalahan lingkungan. Salah satu komitmen masyarakat dan pemerintah internasional dalam menjaga bumi dari pencemaran dan kerusakan adalah melalui pelaksanaan Pendidikan Lingkungan Hidup (Environment Education), yang merupakan kunci untuk mempersiapkan masyarakat dengan pengetahuan, keahlian, nilai dan sikap peduli lingkungan sehingga dapat berpartisipasi aktif dalam memecahkan masalah lingkungan.. Penyuluhan tentang peuli lingkungan dalam program pengabdian ini dimaksudkan sebagai langkah awal pembentukan karakter peduli lingkungan ditengah masyarakat. Pengabdian ini dilakukan pada Pangambaten, Kabupaten Tanah Karo, Provinsi Sumatera Utara. Pengabdian ini dilakukan dengan dua metode, yakni metode ceramah interaktif (interactive presentation). Kegiatan pengabdian ini dilakukan dengan tahapan kegiatan: 1) Penyamaan Persepsi Kelompok Masyarakat,2) Pembinaan kelompok, 3) Penyuluhan Pemahaman Tentang menumbuhkan kepedulian lingkungan terhadap kebersihan lingkungan dengan menggerakkan kembali tradisi gotong royong.
\end{abstract}

Kata Kunci: Desa Pangambatan, Kearifan lokal, Pengabdian Lingkungan

\section{PENDAhUluan}

Sebagai bagian dari masyarakat karo yang tinggal di daerah yang tanahnya yang subur, mayaoritas masyarakatnya hidup bertani dan sebagian kecil pegawai negeri dan juga berdagang buah-buahan sebagai pendapatan tambahan. Sebagai petani, mereka bertani padi, berladang, dan sekaligus beternak yang hasilnya untuk kebutuhan sehari-hari. Hasil pertanian seperti buah-buahan sebagian mereka jual karena di desa pengambatan merek selalu diramaikan oleh pengunjung wisatawan baik lokal dan mancanegara. Buah-buahan yang menjadi andalan masyarakat merek dan pengambatan sebagai oleh-oleh bagi pengunjung yang datang ke desa pengambatan. 
Sebagai desa wisata, desa Pangambaten mempunyai masalah dalam menghadapi tantangan lingkungan terkait dengan kebersihan lingkungan, sehingga muncul kebutuhan untuk mendidik dan memberi informasi kepada masyarakat mengenai permasalahan lingkungan. Salah satu komitmen masyarakat dan pemerintah internasional dalam menjaga bumi dari pencemaran dan kerusakan adalah melalui pelaksanaan Pendidikan Lingkungan Hidup (Environment Education), yang merupakan kunci untuk mempersiapkan masyarakat dengan pengetahuan, keahlian, nilai dan sikap peduli lingkungan sehingga dapat berpartisipasi aktif dalam memecahkan masalah lingkungan. Pendidikan Lingkungan Hidup menurut konvensi UNESCO di Tbilisi (1997) merupakan suatu proses yang bertujuan untuk menciptakan suatu masyarakat dunia yang memiliki kepedulian terhadap lingkungan dan peduli terhadap masalah-masalah yang terkait di dalamnya serta memiliki pengetahuan, motivasi, komitmen, dan keterampilan untuk bekerja, baik secara perorangan maupun kolektif dalam mencari alternatif atau memberi solusi untuk membenahi lingkungan dengan bergotong royong yang dilakukan oleh semua elemen masyarakat.

Pangambaten merupakan salah satu desa yang ada di kecamatan Merek, Kabupaten Karo, provinsi Sumatra Utara, Indonesia. Desa pangambatan terkenal dengan Tanah yang subur dan juga dekat dengan lokasi-lokasi wisata lokal seperti Air terjun Sipiso-piso, tongging, paropo, silalahi yang merupakan daerah pinggiran danau Toba yang berada di Kabupaten Karo. Sesuai dengan keadaan alamnya yang tanahnya subur dan terletak dekat dengan permukaan Danau Toba, daerah ini juga tidak ubahnya dengan daerah tanah karo lainnya yaitu terkenal subur. Dimana tanah ini bercampur dengan bahan yang berasal dari letusan Gunung Toba di zaman dulu..

Selama ini anggapan hidup bersih dan sehat adalah tanggung jawab dokter atau bidang kesehatan. Padahal anggapan seperti itu tidak dibenarkan, karena hidup bersih dan sehat adalah hak dan kewajiban semua orang. Ketika sikap manusia mengenai lingkungan dan dampak dari kegiatan manusia sangat tidak terurus dan terpikirkan, saat lingkungan rusak dan ekosistem hancur maka keseimbangan antara kehidupan dengan kehidupan lainnya akan berubah, hal ini memberikan dampak negatif bagi setiap makhluk hidup yang ada disekitarnya. Maka dengan demikian dibutuhkan sikap peduli terhadap lingkungan. Dengan adanya sikap peduli terhadap lingkungan akan menjadikan suasana yang nyaman, tentram, bebas dari kerusakan lingkungan. Sikap peduli terhadap lingkungan bisa ditunjukkan dengan adanya sikap yang positif terhadap lingkungan. Seperti menjaga keseimbangan lingkungan memahami pentingnya menjaga kebersihan lingkungan sampai menjaga lingkungan dari polusi.

Menurut Soeryani (2005 :27), pendidikan lingkungan hidup adalah pengajaran serta penyebarluasan filsafat dan dasar-dasar pemahaman tentang lingkungan hidup. Hal ini berarti bahwa pendidikan lingkungan akan menjadikan peserta didik mempunyai kepedulian terhadap lingkungan. Filsafat itu sendiri adalah kecintaan terhadap kearifan, sehingga pengajaran tentang filsafat berarti mendorong diri kita guna memperoleh kearifan itu untuk berperilaku sebaik mungkin dalam hidup ini. Filasafat lingkungan hidup adalah kecintaan terhadap kearifan sikap dan perilaku kita. Jadi filsafat lingkungan hidup merupakan pencarian untuk mendapatkan kearifan guna menata sikap dan perilaku seserasi mungkin dalam lingkungan di mana kita berada.

Orientasi pengembangan desa wisata seyogyanya untuk meningkatkan kesejahteraan masyarakat desa. Upaya ini perlu kesabaran dalam melakukan pengkajian, perencanaan, pengembangan dan pemanfaatan secara wajar dan adil, baik terhadap alam maupun manusianya. Tidak hanya manusia yang memiliki hak, juga alam lingkungan memiliki hak yang harus dan wajib ditunaikan oleh manusia yang memanfaatkannya. Optimalisasi daya dukung memerlukan pemahaman yang baik mengenai karakter, dinamika dan kecenderungan yang berkembang. Ini perlu dicermati dan diikuti, sehingga perkembangan itu mengarah pada kelestarian, bukan kerusakan. Keberadaan desa wisata dalam perjalanan pembangunan pariwisata di Tanah Air sudah sedemikian penting. Desa wisata sudah mampu mewarnai variasi destinasi yang lebih dinamis dalam suatu kawasan pariwisata, sehingga pariwisata tidak selalu terjebak dalam trend pengembangan bercorak mass tourism. Dalam konteks kepariwisataan Bali, perkembangan desa wisata menjadi bagian tak terpisahkan dari pasang-surut perkembangan pariwisata. Melalui desa wisata, pariwisata membuktikan keberpihakannya kepada semangat 
pariwisata sebagai penyerap tenaga kerja pedesaan, sebagai penggerak pertumbuhan ekonomi wilayah, dan sebagai alat pengentasan kemiskinan (pro job, pro growth, pro poor).

Atas dasar analisis situasi tersebut, diperlukan pengabdian masyarakat untuk mengedukasi masyarakat desa pangambatan untuk menumbuhkan kepedulian lingkungan dengan menerapkan nilai kearifan lokal bergotong-royong sehingga menjadikan desa Pangambatan sebagai Desa wisata yang bersih, nyaman, dan bebas dari polusi sampah sehingga melalui itu semua dapat meningkatkan kunjungan wisata dan pengembangan desa pangabatan sebagai destinasi wisata.

\section{METODE PELAKSANAAN}

Pengabdian ini dilakukan dengan dua metode yakni metode ceramah interaktif (interactive presentation) dan metode pelatihan lapangan (field workshop). Ceramah interaktif dilaksanakan untuk memberdayakan masyarakat di lokasi pengabdian tentang pengetahuan lokal yang berhubungan dengan menumbuhkan kepedulian lingkungan,penerapan kearifan lokal gotong royong, dan performansi penyampaian kepada masyarakat setempat sehingga mereka memahami informasi tentang kearifan lokal gotong royong terhadap kebersihan lingkungan di lokasi pengabdian. Ceramah interaktif ini diwujudkan dalam bentuk FGD (focus group discussion).

Metode pelatihan lapangan digunakan untuk memberdayakan masyarakat di lokasi pengabdian tentang cara membuat dan mengemas alat kerajianan tangan secara baik untuk keperluan pengembangan destinasi wisata. Pelatihan lapangan ini diwujudkan dalam bentuk demo membuat kerajianan tangan di lokasi pengabdian.

Paradigma pelaksanaan pengabdian ini dilakukan dengan paradigma kualitatif model interaktif (Miles, dkk, 2014:31), yakni mengintegrasikan mulai dari pengumpulan data (data collection), penyajian data (data condensation), kondensasi data (data condensation), dan kesimpulan: penarikan/verifikasi (conclusion:drawing/verifying). Hasil pelaksanaan itu akan disusun dalam bentuk laporan pengabdian.

\section{HASIL DAN PEMBAHASAN}

\subsection{Meningkatan Pengetahuan masyarakat setempat tentang kepedulian lingkungan di desa pangambatan .}

Pariwisata yang memiliki keunikan budaya, cinderamata yang khas serta panorama yang indah dapat memberikan kesan baik bagi setiap wisatawan sehingga akan menimbulkan rasa cinta pada alam, rasa cinta pada budaya serta cinta tanah air Indonesia. Indonesia merupakan negara yang memiliki potensi kekayan alam yang luar biasa. Potensi tersebut perlu dilestarikan untuk menjamin berlanjutnya pembangunan. Upaya untuk menjaga kelestariannya adalah menjadikan lingkungan yang kaya akan keanekaragam hayati dan potensi alam menjadi kawasan konservasi. Salah satunya adalah kawasan pelestarian alam yang dikelola dengan sistim zonasi dan dimanfaatkan untuk penelitian, ilmu pengetahuan, pendidikan, menunjang kebudayaan, pariwisata dan rekreasi, salah satunya yaitu Objek Wisata Desa wisata Pengambatan di Desa Pangambaten, Kabupaten Tanah Karo, Provinsi Sumatera Utara. Objek wisata Desa Pengambatan yang dikelola oleh Dinas Pariwisata sudah selayaknya daerah ini menjadi berkembang dan banyak diminati orang. Desa Pengambatan memiliki potensi berupa ekosistem hutan yang luas, keanekaragaman hayati yang tinggi, daerah resapan air yang potensial serta ekowisata dengan panorama alam yang indah. Serta tidak terkecuali termasuk objek penelitian dan pendidikan. Pengelolaan diharapkan mampu untuk melindungi, memanfaatkan sekaligus melestarikan sumber daya hayati dan ekosistemnya secara optimal sehingga dapat meningkatkan kesejahteraan masyarakat. Potensi alam dikelola dan dikembangkan sebagai kawasan pariwisata.

Menurut UU No 32 Tahun 2009 menyatakan bahwa, "Lingkungan hidup dapat diartikan kesatuan ruang dengan semua benda, daya keadaan, dan makhluk hidup, termasuk manusia dan perilakunya yang mempengaruhi perikehidupan dan kesejahteraan manusia serta makhluk hidup 
lainnya". Lingkungan hidup mencakup dua hal yaitu sosiosistim (komponen sosial) dan ekosistim (komponen hayati dan non hayati) yang saling berinteraksi dan ikut menentukan kelangsungan hidup manusia. Komponen lingkungan ekosistim terdiri dari komponen hayati (biotik) dan non hayati (abiotik). Lingkungan hayati (biotik) adalah semua makhluk hidup yang ada di sekitar individu baik tumbuh-tumbuhan, hewan, dan manusia. Lingkungan non hayati (abiotik) adalah segala benda mati dan keadaan fisik yang ada di sekitar individu-individu, misalnya : batu-batuan, mineral, air, udara; unsur-unsur iklim, cuaca, suhu, kelembapan, angin, faktor gaya berat, dan lain-lain. Masalah lingkungan hidup merupakan gejala dari sikap pembangunan yang kurang menyadari pentingnya pelestarian lingkungan hidup. Berkembangnya ilmu pengetahuan dan teknologi menyebabkan kemajuan disegala bidang, sekaligus menimbulkan dampak lingkungan yang tidak diinginkan.

Dampak lingkungan yang terjadi saat ini banyak disebabkan karena tindakan manusia dalam pembangunan yang tidak memperhatikan kelestarian lingkungan hidup. Manusia sebagai subjek pembangunan tidak memiliki etika lingkungan yang benar sehingga bersikap superior terhadap alam. Hal ini mengakibatkan kemampuan daya dukung lingkungan semakin berkurang karena sumber daya alamnya diekploitasi secara besar-besaran untuk kepentingan hidup manusia. Disamping dampak tersebut timbul pula beragam pencemaran seperti alam. Disamping Sumberdaya yang tidak pernah habis mengalami kerusakan akibat dari pengelolaan pariwisata yang kurang tepat, misalnya keindahan disekitar kawasan merek pengambatan mengalami kerusakan, dan ini mengakibatkan jumlah wisatawan yang datang ke lokasi mengalami penurunan. Masalah kebersihan, pencemaran dan perusakan lingkungan di dalam kawasan Objek Wisata Desa wisata Pengambatan jika tidak segera diatasi akan menimbulkan dampak negatif dari segi ekologi, ekonomi dan sosial sekitar kawasan.

Dengan banyaknya sampah serta vandalisme di sekitar kawasan dapat menyebabkan potensi alamiah Desa Pengambatan rusak. Keindahan wisata alam yang bersih dan alami terganggu, maka wisatawan akan malas berkunjung kembali. Hal ini dapat menyebabkan usaha masyarakat sekitar kawasan yang mengandalkan pariwisata akan terganggu, pada akhirnya dapat menimbulkan konflik sosial. Kerusakan lingkungan ini perlu ditanggapi secara serius untuk menjamin pelestarian lingkungan dan pembangunan. Untuk mengatasi masalah tersebut, perlu diselidiki penyebab terjadinya pencemaran dan kerusakan lingkungan di kawasan Desa pengambatan. Cara mengatasi masalah kependudukan dan lingkungan hidup tidak dapat hanya dengan melakuakan usaha- usaha teknis semata melainkan harus didukung dengan upaya edukatif dan persuasif. Upaya yang bersikap edukatif ialah pelaksanaan pendidikan, kependudukan, dan lingkungan hidup baik secara formal maupun non formal. Pendidikan kependudukan dan lingkungan hidup secara formal dilaksanakan di sekolah-sekolah, sedangkan secara non formal dilakukan di luar sekolah. Upaya pemahaman perilaku manusia terhadap lingkungan merupakan kajian yang menarik dan penting untuk dipelajari sebagai salah satu bentuk penyelamatan lingkungan. Salah satunya adalah meneliti faktor-faktor yang mempengaruhi perilaku wisatawan dalam menjaga kebersihan lingkungan.

Berkaitan dengan permasalahan pencemaran kawasan objek desa wisata pangambatan, banyak wisatawan memasuki kawasan tidak sesuai dengan aturan atau prosedur yang benar, tidak kurang para wisatawan mengabaikan kaidah konservasi. Hal ini dikarenakan rendahnya pengetahuan dan sikap wisatawan tentang bagaimana perilaku yang baik dan selaras ketika berada di kawasan konservasi. Faktor lain yang mempengaruhi perilaku adalah tujuan, motivasi, umur, tingkat pendidikan, tingkatan ekonomi, kepribadian mereka sangat beragam dan tidak bisa dihomogenkan. Sisi lain yang berpengaruh adalah pengelolaan wisata alam yang kurang memperhatikan daya dukung lingkungan. Pengelolaan sampah dan sarana kebersihan yang kurang lengkap dapat juga sebagai faktor pemicunya. kawasan wisata alam ini harus dipertahankan kelestarian lingkungan dan kebersihannya supaya tetap menjadi daya tarik kunjungan wisatawan di kawasan Desa wisata Pengambatan Kabupaten Karo. 


\subsection{Keterampilan masyarakat setempat dalam penatalaksanaan gotong-royong untuk mewujudkan desa wisata yang nyaman dan bersih}

Konsep pemberdayaan masyarakat di Desa Wisata Pengambatan berlandaskan Sapta pesona yaitu rasa aman, tertib,bersih, sejuk, indah,ramah tamah, dan kenangan. Sehingga mewujudkan desa wisata yang memberi keharmonisan, kesejahteraan, kebahagiaan kepada pengunjungnya. Hal ini akan memberi gambaran hubungan yang harmonis antara manusia dengan Tuhan, antar sesama manusia, dan manusia dengan lingkungannya. Proses pemberdayaan masyarakat melalui pengembangan desa wisata di Desa pengambatan melalui tiga tahapan, meliputi tahap penyadaran, tahap pengkapasitasan dan terakhir tahap pemberian daya. Tahap pertama adalah tahap penyadaran dimana pada tahap ini dilakukan sosialisasi pembentukan desa wisata kepada masyarakat desa. Proses sosialisasi dilakukan oleh para tokoh desa melalui rapat-rapat desa dengan memberikan pemahaman kepada masyarakat tentang pembentukan desa wisata di lingkungan tempat tinggal mereka. Proses ini sejak awal tidak menemukan kendala yang berarti karena sebelum berstatus sebagai desa wisata, Desa pengambatan merupakan suatu desa konservasi, yaitu suatu desa yang berusaha untuk melestarikan budaya, adat istiadat, hukum adat budaya Karo, dan tata cara kehidupan sehari-hari serta lingkungannya untuk diwariskan kepada generasi penerus agar tidak pudar seiring berjalannya waktu.

Upaya pelestarian di Desa pengambatan dari segi fisik sudah dimulai dari awal tahun 2000 an, yaitu dengan mempertahankan keaslian bahan dan bentuk bangunan rumah warga yang ramah lingkungan yaitu Untuk menjaga kenyamanan dan keasrian lingkungan, masyarakat setempat membuat taman di depan rumah mereka yang ditanami dengan aneka ragam tanaman bunga. Desa pengambatan telah lama dikenal memiliki potensi wisata alam dan wisata budaya berupa arsitektur bangunan yang khas, seiring berjalannya waktu masyarakat Desa pengambatan berusaha untuk mengembangkan potensi wisata lain yang dikembangkan dan digali dari aktivitas kehidupan warga sehari-hari dan dikemas dalam bentuk atraksi wisata meliputi atraksi menganyam, membuat makanan tradisional, mengolah kopi, memetik buah jeruk dan strawberry, keindahan Alam, dan atraksi budaya Karo. Atraksi ini ditawarkan kepada wisatawan dalam bentuk paket ataupun atraksi lainnya sesuai permintaan wisatawan.

Pembangunan desa wisata tidak lepas dari peran serta masyarakat. Oleh sebab itu diperlukan adanya situasi dan kondisi masyarakat yang memiliki pola berpikir yang sadar wisata. Penerapan sikap sadar wisata diharapkan akan mengembangkan pemahaman dan pengertian yang proporsional di antara berbagai pihak, sehingga pada gilirannya akan mendorong masyarakat untuk berperan serta dalam pariwisata. Pengembangan desa wisata di Desa pengambatanmendapat dukungan dari masyarakat setempat yang terlihat dari keterlibatan mereka dalam menjaga dan merawat kebersihan dan kenyamanan lingkungan, melestarikan budaya baik secara fisik maupun non fisik serta partisipasi mereka dalam mendukung berbagai kegiatan atraksi wisata. Partisipasi aktif masyarakat yang dapat dilakukan adalah dengan menghidupkan kembali gotong royong untuk menjaga kebersihan lingkungan sehingga dengan bergotong royong maka akan menumbuhkan nilai kebersamaan antar masyarakat di desa pengambatan kabupaten merek yang menjadi destinasi ekowissata. Partisipasi masyarakat lainnya nampak dalam menyediakan berbagai akomodasi wisata yang dibutuhkan oleh wisatawan berupa tersedianya tempat penginapan atau homestay dan warung yang menyediakan berbagai macam makanan dan minuman serta aneka cinderamata.

Tahap kedua pengkapasitasan. Peran serta pemerintah sebagai salah satu stakeholder pariwisata sangat dibutuhkan pada tahap ini. Pemerintah dan masyarakat sebenarnya memiliki tanggung jawab yang sama dalam pengembangan pariwisata. Namun demikian, pemerintah seharusnya lebih berperan dalam mengajak, menggugah, dan menggairahkan masyarakat. Tugas tersebut salah satunya diwujudkan dalam bentuk kerja sama yang baik antara pemerintah dan masyarakat (Saryani, 2013:51-52). Peranan pemerintah di Desa pengambatan dalam hal ini adalah meningkatkan sumber daya manusia melalui bimbingan, penyuluhan dan pelatihan di bidang kepariwisataan maupun kepada kelompok masyarakat yang memiliki usaha kerajinan di area obyek wisata. Untuk meningkatkan sumber daya manusia di bidang kepariwisataan, pemerintah melalui 
Dinas Kebudayaan dan Pariwisata Pemerintah Daerah Kabupaten Karo Bidang Bimbingan dan Penyuluhan tiap tahun mengadakan program pelatihan kepada kelompok-kelompok sadar wisata yang ada di Kabupaten Karo, selain itu pemerintah melalui dinas kesehatan dan dinas perindustrian dan perdagangan memberikan bantuan berupa bimbingan, penyuluhan dan pelatihan kepada kelompok perajin baik perajin bambu dan perajin minuman tradisional untuk meningkatkan kualitas hasil kerajinan mereka.

\subsection{Potensi dan daya Tarik wisata pangambatan dengan kearifan lokal}

Potensi wisata Desa pengambatan, Kabupaten Karo memiliki daya tarik wisata yang mampu ditonjolkan sebagai suatu keunggulan produk wisata meliputi geografis, demografis, sejarah maupun panorama alam. Wisata yang sudah berkembang di Kabupaaten Karo memanfaatkan potensi : 1. Sumberdaya alam (natural resources) yang meliputi lanskap alami, air terjunsipiso-piso, Pesona bentang alam, serta lahan pertanian dan perkebunan masyarakat [. 2. Sumberdaya kebudayaan (cultural resources) yang meliputi adat-istiadat Karo, kesenian tradisional, kerajinan masyarakat di Kabupaten Karo, dan kebudayaan warisan (cultural heritage) yang sebagian besar berwujud peninggalan (artifact)

Dukungan masyarakat terhadap pengembangan pariwisata di Desa pengambatan ini tampak dari berkembangnya usaha jasa pariwisata, antara lain: 1. Wisata Pendidikan Kuliner Wisata pendidikan kuliner adalah salah satu kegiatan wisata kreatif yang telah mendapat perhatian besar dari para wisatawan.. Pelatihan memasak masakan tradisional untuk para wisatawan berlokasi di banyak tempat sekitar objek wisata diDesa pengambatan, misalnya yang berlokasi di Berastagi. Mereka menggunakan budaya dan cara hidup masyarakat setempat untuk mempromosikan pariwisata kreatif. Kegiatannya termasuk mengajak wisatawan berbelanja di pasar tradisional, memasak makanan khas Desa pengambatan menggunakan menu yang dirancang untuk wisatawan seperti Gule kuta-kuta, manuk getah, cimpa dll. Membawa wisatawan untuk berbelanja di pasar tradisional menjadi cara untuk membantu mendistribusikan pendapatan dari wisatawan ke masyarakat, sehingga memungkinkan masyarakat untuk berpartisipasi dalam pariwisata kreatif. Wisatawan akan mengalami, memiliki kesempatan untuk berinteraksi dengan pedagang di pasar tradisional dan terkesan ketika disambut dengan senyum dan keramahan masyarakat.

Kegiatan Bertani Secara Tradisional Dan Organik Kegiatan bertani secara tradisional dengan pemupukan organik dikenalkan di tempat tujuan wisata yang berlokasi di Merek. Destinasi wisata ini mengangkat pengolahan lahan pertanian secara tradisional dan pemupukan tanaman dengan pupuk organik sebagai daya tarik. Wisatawan yang datang ke destinasi ini, selain untuk menikmati keindahan, juga dapat belajar bertani secara organik maupun praktek melaksanakan kegiatan bertani organik.Destinasi wisata juga dilengkapi dengan ahli pertanian organik yang berperan sebagai pemandu para tamu yang datang. Mengolah susu sapi adalah satu peran masyarakatdalam mendukung pengembangan pariwisata diDesa pengambatan adalah dikembangkannya desa wisata di Desa Pangambatan . Festival budaya tradisional Karo. Kegiatan festifal budaya ini menjadi acara tahunan pemerintah daerah kabupaten Desa pengambatan. Dalam festifal itu ditampilkan berbagai pertunjukan seni maupun kegiatan budaya lainnya yang masih berkembang di desa-desa di wilayah kabupaten Desa pengambatan.

\section{KESIMPULAN}

Wisata kreatif adalah bentuk pariwisata yang sesuai dengan budaya dan cara masyarakat. Masyarakat dapat mengelola pariwisata mereka sendiri. Dalam hal area, itu adalah pariwisata di daerah yang terutama terhubung dengan cara masyarakat dan alam dengan atraksi alam dengan identitas kawasan serta budaya dan sejarah daerah tertentu. Dalam hal manajemen, Desa wisata pengambatan harus menajdi desa wisata yang bersih dan nyaman dikunjungi oleh wisatawan dan memiliki lingkungan yang bersih dan asri dan memiliki manajemen yang berkelanjutan dengan 
memungkinkan wisatawan, komunitas, dan masyarakat setempat serta orang-orang yang terafiliasi untuk berpartisipasi dalam konservasi budaya dan lingkungan di tempat-tempat wisata komunitas. Dalam hal aktivitas dan proses, itu adalah pariwisata yang memfasilitasi pembelajaran dengan mendidik tentang budaya dan cara-cara komunitas serta lingkungan dan ekosistem pariwisata untuk menciptakan kesadaran dan kesadaran dalam wisatawan, komunitas, masyarakat lokal dan orangorang yang terafiliasi.

Dalam hal partisipasi, itu adalah pariwisata yang sadar akan partisipasi dari wisatawan, komunitas, masyarakat lokal dan orang-orang yang terafiliasi. Dengan demikian, menggunakan kearifan lokal untuk mempromosikan pariwisata melalui proses pariwisata kreatif dalam rangka menciptakan pengembangan pariwisata berkelanjutan ditargetkan pada masyarakat. Keseimbangan harus dibuat dalam hal ekonomi, masyarakat dan lingkungan sehingga masyarakat, dengan keseimbangan ini, dapat mengembangkan pariwisata berkelanjutan.

Pentingnya menumbuhkan kepedulian lingkungan terhadap kebersihan lingkungan dengan menggerakkan kembali tradisi gotong royong, sehingga masyarakat di desa pangambatan memiliki cara hidup yang bersih dan terwujudnya desa wisata yang nyaman, bersih, asri, dan tentunya penuh kenangan sehingga meningkatka jumlah kunjungan wisata kedepannya.

\section{UCAPAN TERIMAKASIH}

Penulis dan Tim mengucapkan Terimakasih kepada Lembaga LPPM Universitas Sumatera Utara yang memberikan sponsor dan dana sehingga pengabdian ini terlaksana. Penulis juga mengucapkan terimakasih kepada Kepala Desa Pangambatan, masyarakat Pangambatan yang berpartisipasi dalam pengabdian masyarakat, dan semua pihak yang membantu terlaksananya Pengabdian masyarakat ini.

\section{DAFTAR PUSTAKA}

Faruq Muhyi, 2006. Pendidikan jasmani Olahraga dan kesehatan. Jakarta : Grasindo Heryanti Feni. Kebersihan dan Kesehatan Lingkungan Hidup. Jurnal Ilmiah. Desember 2013

Farida, Annis. 2016. Kontribusi pendidikan POKDARWIS (Kelompok Sadar Wisata) terhadap upaya pengembangan Desa wisata Dokan Kandri Kota Semarang. Skripsi. Semarang: Fakultas Ilmu Sosial UNNES.

Hakim, Luchman. 2004. Dasar-Dasar Ekowisata. Malang: Bayumedia.

Haryati, Sri. 2016. Jurnal Ketahanan Nasional: UGM. jurnal.ugm.ac.id/JKN. (8 Februari 2017) Kemenpar.go.id/PERMEN_TENTANG_PEDOMANPNPM_2013.pdf (10 Februari 2017)

Keraf, A. Sonny. 2005. Etika Lingkungan. Jakarta: Kompas.

Koentjaraningrat. 2005. Buku Pengantar Antropologi 1. Jakarta: Rineka Cipta.

Mariyana, Dkk. 2010 Pengelolaan Lingkungan Belajar. Jakarta : Kencana Prenada Media Group Maryati dan Suryawati. 2001. Sosiologi 2. Jakarta: Esis.

Mulyono, Sungkowo Edy dan Laela Hajaroh. 2014. Partisipasi Anggota Kelompok Swadaya Masyarakat dalam Pengembangan Desa wisata Dokan. [Journal of Non Formal Education and Community Empowerment]. (05 Januari 2016). Semarang: UNNES. journal.unnes.ac.id/ 
Flansius Tampubolon et.al. Socialization of Efforts to Increase Environmental Awareness

Nuryanti, Wiendu.1993. Concept, Perspective, and Challenges, makalah bagian dari Laporan Konferensi Internasional mengenai Pariwisata Budaya. Yogyakarta:Gadjah Mada University Press.

Ariwidodo, Eko. (2014). Relevansi Pengetahuan Masyarakat Tentang Lingkungan Dan Etika Lingkungan Dengan Partisipasinya Dalam Pelestarian Lingkungan. Jurnal Nuansa. 